Gut, 1971, 12, 48-50

\title{
Management of bleeding oesophageal varices by draining lymph from the thoracic duct
}

\author{
D. V. DATTA, SAMANTA A. K. SINGH, B. S. PATRA, V. K. SAINI, AND \\ P. N. CHHUTTANI
}

From the Division of Hepatic Diseases, Department of Medicine, Postgraduate Institute of Medical Education and Research, Chandigarh, India

SUMMARY The thoracic duct was cannulated in six patients who were actively bleeding from varices and had not responded to conservative treatment but draining lymph from the thoracic duct did not control bleeding in five patients. There was no drop in intrasplenic pulp pressure following this procedure when recorded in three of these patients. Bleeding stopped in one patient after lymph had been drained for nine and a half hours, and there was only a modest change in intrasplenic pressure. The therapeutic use of this technique to control oesophageal varices could not be substantiated.

The emergency treatment of active bleeding from oesophageal varices is often unsatisfactory. Oesophageal tamponade with a Sengstaken tube, vasopressin, and gastric cooling have been used with some success (Sherlock, 1968). Emergency surgery carries a high mortality rate (Sherlock, 1968). A new approach to meet this difficult problem was suggested by the finding that draining lymph from the thoracic duct in patients with cirrhosis of the liver lowers portal pressure (Dumont and Mulholland, 1961). On the basis of their findings, this procedure has been used as an emergency treatment for bleeding varices by Dumont and Mulholland (1961), Bowers, McKinnon, Marino, and Culverwell (1964), and Cueto and Currie (1967). These reports have emphasized the immediate cessation of bleeding due to oesophageal varices following this procedure. Impressed with these reports and the simplicity of the procedure, we have assessed its efficacy in controlling the bleeding from oesophageal varices in six patients when other routine measures had failed.

\section{Materials and Methods}

\section{PATIENTS}

Six patients with bleeding oesophageal varices associated with portal hypertension were studied (Table Received for publication 29 September 1970.
I). All patients continued to bleed despite blood transfusions, gastric lavage with ice-cold water, and Sengstaken oesophageal compression for four to 24 hours. None of the patients was considered fit for emergency surgery.

At necropsy four patients showed macronodular cirrhosis and two noncirrhotic portal fibrosis (Indian Council of Medical Research, 1969). None had peptic ulcer.

\section{ROUTINE}

The Sengstaken tube was deflated after it had failed to control bleeding. Blood transfusion was continued in these patients, and the thoracic duct was cannulated and lymph drained using the method of Dumont and Mulholland (1961). The stomach was aspirated every 30 minutes through an indwelling Ryle's tube. Control of haemorrhage was verified by the disappearance of blood in the gastric aspirate together with serial blood pressure and pulse recordings.

The intrasplenic pressure and thoracic duct end pressure were measured with a saline manometer with a zero point at $5 \mathrm{~cm}$ below the sternal angle, the patient lying in the supine position.

Liver function tests were carried out by standard methods (King and Wooton, 1959). All these patients were given bowel washes and oral neomycin, and vitamin $\mathrm{K}$ and water-soluble vitamins were injected. 


\section{Results}

The clinical and biochemical features of the patients under study are shown in Table I and other findings are summarized in Table II.

The thoracic duct was distended in all the six patients. Lymph was drained for one to 27 hours (Table II); the total amount of lymph drained ranged from 240 to $6,500 \mathrm{ml}$. Lymph was haemorrhagic in all patients. The total lymph protein content varied from 1.0 to $2.7 \mathrm{~g} \%$.

In five patients (nos. 1-5) bleeding did not stop nor was there any change in intrasplenic pressure following this procedure when recorded in three of these patients. Thoracic duct end pressure did not change significantly in four patients though it fell in one (no. 3). Two patients (nos. 1 and 2) had very severe haematemesis even when the thoracic duct lymph was being drained. Case 1 had a severe episode at one and 12 hours, and case 2 at 3.5 and 27 hours after the start of lymph drainage.

Bleeding stopped in one patient (case 6) after thoracic duct lymph drainage when other measures had failed to control it. This effect was obvious nine and a half hours after lymph drainage and remained so while lymph drainage was continued. There was only a modest change in intrasplenic pressure (365 to 340 ) and the thoracic duct end pressure fell from 400 to $200 \mathrm{~mm}$ saline.

All six patients eventually died, four of them of massive haemorrhage and hepatic coma. One patient (no. 2) died of hepatic coma following Tanner's portosystemic venous disconnexion for portal hypertension and the other (no. 6) from a massive haemorrhage after thrombosis of the elective lienorenal shunt.

\section{Discussion}

Dumont and Mulholland (1961) reported that patients with cirrhosis of the liver show a distended thoracic duct containing lymph under high pressure. They also demonstrated that draining the distended thoracic duct was followed by a decrease in the size

\begin{tabular}{|c|c|c|c|c|c|c|c|c|c|c|c|c|}
\hline Case & $\begin{array}{l}\text { Age }(y r) \\
\text { and } \\
\text { Sex }\end{array}$ & $\begin{array}{l}\text { Duration of } \\
\text { Illness } \\
(y r)\end{array}$ & $\begin{array}{l}\text { Haemat- } \\
\text { emesis } \\
\text { (day) }\end{array}$ & $\begin{array}{l}\text { Level of } \\
\text { Conscious- } \\
\text { ness }\end{array}$ & Ascites & $\begin{array}{l}\text { Spleen } \\
(\mathrm{cm})\end{array}$ & $\begin{array}{l}\text { Haemoglobin } \\
(\mathrm{g} / 100 \mathrm{ml})\end{array}$ & $\begin{array}{l}\text { Prothrombin } \\
\text { Index }(\%)\end{array}$ & $\begin{array}{l}\text { Serum } \\
\text { Bilirubin } \\
\text { (mg/100 ml }\end{array}$ & $\begin{array}{l}S G P T \\
(I U / l) \\
l l)\end{array}$ & $\begin{array}{l}\text { Serum } \\
\text { Albumin| } \\
\text { Globulin } \\
(\mathrm{g} / 100 \mathrm{ml})\end{array}$ & $\begin{array}{l}\text { Blood } \\
\text { Transfused } \\
\text { (ml) }\end{array}$ \\
\hline $\begin{array}{l}1 \\
2 \\
3 \\
4 \\
5 \\
6\end{array}$ & $\begin{array}{l}50 \mathrm{M} \\
40 \mathrm{M} \\
45 \mathrm{M} \\
40 \mathrm{~F} \\
34 \mathrm{~F} \\
30 \mathrm{~F}\end{array}$ & $\begin{array}{r}1 \\
2 \\
1 \\
7 \\
15 \\
2\end{array}$ & $\begin{array}{l}1 \\
1 \\
1 \\
1 \\
4 \\
2\end{array}$ & $\begin{array}{l}\text { Precoma } \\
\text { Normal } \\
\text { Precoma } \\
\text { Precoma } \\
\text { Precoma } \\
\text { Normal }\end{array}$ & $\begin{array}{l}++ \\
++ \\
++ \\
+ \\
+ \\
+\end{array}$ & $\begin{array}{l}-3 \\
8 \\
6 \\
8 \\
2\end{array}$ & $\begin{array}{r}10.0 \\
10.0 \\
2.5 \\
11.0 \\
3.0 \\
8.0\end{array}$ & $\begin{array}{l}74 \\
64 \\
65 \\
73 \\
55 \\
84\end{array}$ & $\begin{array}{l}0.2 \\
0.2 \\
1.0 \\
1.2 \\
2.5 \\
1.0\end{array}$ & $\begin{array}{r}2.5 \\
10.0 \\
10.0 \\
9.6 \\
\overline{22.9}\end{array}$ & $\begin{array}{l}2 \cdot 2 / 4 \cdot 2 \\
2 \cdot 8 / 3 \cdot 8 \\
3 \cdot 0 / 2 \cdot 5 \\
2 \cdot 8 / 2 \cdot 8 \\
2 \cdot 8 / 2 \cdot 5 \\
2 \cdot 8 / 3 \cdot 2\end{array}$ & $\begin{array}{r}1,000 \\
1,500 \\
1,500 \\
500 \\
1,500 \\
1,000\end{array}$ \\
\hline
\end{tabular}

Table I Presenting features

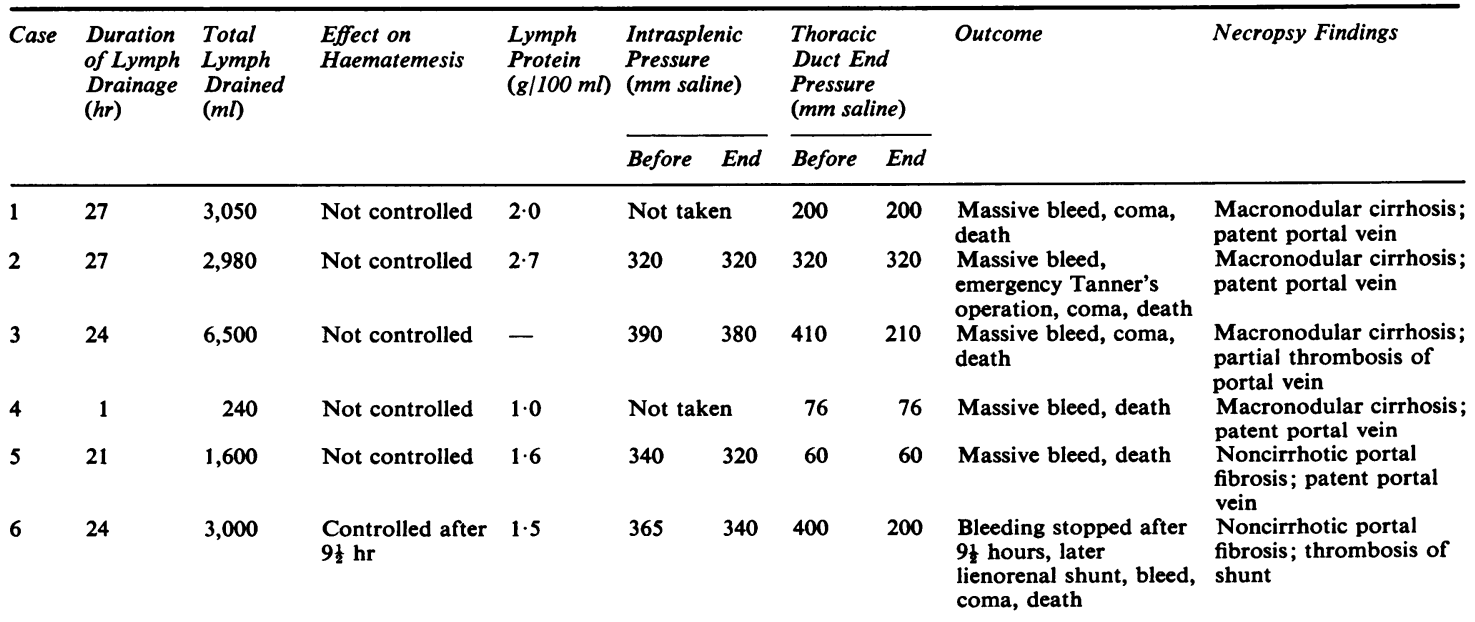


of the liver, the disappearance of ascites, and a reduction in portal pressure. In view of these encouraging effects on portal pressure, they cannulated the thoracic duct in two patients who were bleeding from oesophageal varices. The bleeding stopped immediately after the thoracic duct had been cannulated and drained. No effect on intrasplenic pressure was reported in these patients. Similar experiences have been reported by Bowers et al (1964) and by Cueto and Currie (1967). Kessler, Santoni, Tice, and Zimmon (1969), on the other hand, reported control of bleeding in only three of the seven patients with cirrhosis of the liver following this procedure, and they were not impressed with the technique.

Our failure to control bleeding in five of six patients emphasizes that this technique cannot be recommended for the immediate control of bleeding varices. In fact two patients had a fresh bout of severe haematemesis during lymph drainage which had been going on for 12 hours in one patient and for 27 hours in the second patient. Also the intrasplenic pressure did not change during this procedure. However, one patient suffering from non-cirrhotic portal fibrosis did respond when bleeding was arrested nine and a half hours after lymph drainage. This was associated with only a modest change in intrasplenic pressure (from 365 to $340 \mathrm{~mm}$ saline) but the fall in thoracic duct end pressure (from 400 to $200 \mathrm{~mm}$ saline) was significant. In view of the minimal change in intrasplenic pressure following this procedure it is unlikely that draining lymph from the thoracic duct had played any significant part in the arrest of haemorrhage which appears to have occurred spontaneously. It is well known that bleeding in cirrhosis of the liver may not always be due to varices (Sherlock, 1968). However, none of our patients had a haemorrhagic tendency nor was a peptic ulcer found at necropsy.

It was of interest to observe the distended thoracic duct with haemorrhagic lymph not only in patients with cirrhosis of the liver but also in patients with non-cirrhotic portal fibrosis.

We thank Professor B. K. Aikat for access to the necropsy data.

Part of this work was carried out with a grant from the Indian Council of Medical Research.

\section{References}

Bowers, W. F., McKinnon, W. M. P., Marino, J. M., and Culverwell, J. T. (1964). Cannulation of the thoracic duct: its role in the pre-shunt management of hemorrhage due to esophageal varices. J. int. Coll. Surg., 42, 71-76.

Cueto, J., and Currie, R. A. (1967). Cannulation of the thoracic duct and umbilical vein in patients with portal hypertension. Ann. Surg., 165, 408-414.

Dumont, A. E., and Mulholland, J. H. (1961). Alterations in thoracic duct lymph flow in hepatic cirrhosis. Significance in portal hypertension. Ann. Surg., 156, 668-677.

Indian Council of Medical Research Workshop (1969). Non-cirrhotic portal fibrosis. New Delhi.

Kessler, R. E., Santoni, E., Tice, D. A., and Zimmon, D. S. (1969). Effect of lymph drainage on portal pressure and bleeding esophageal varices. Gastroenterology, 56, 538-547.

King, E. J., and Wooton, I. D. P. (1959). Micro-analysis in medical biochemistry, 3rd ed. Churchill, London.

Sherlock, S. (1968). Diseases of Liver and Biliary System, 4th ed. Blackwell, Oxford. 